\title{
A Comparative Study on the Engine Performance and Exhaust Emissions of Biodiesel from Various Vegetable Oils and Animal Fat
}

\author{
Bjorn S. Santos ${ }^{1 *}$, Sergio C. Capareda ${ }^{2}$ \\ ${ }^{1}$ Agricultural Sciences Department, De La Salle Araneta University, Malabon City, Philippines \\ ${ }^{2}$ Department of Biological and Agricultural Engineering, Texas A\&M University, College Station, TX, USA \\ Email: ${ }^{*}$ bjorn.santos@dlsau.delasalle.ph, scapareda@tamu.edu
}

Received 31 July 2015; accepted 7 September 2015; published 11 September 2015

Copyright (C) 2015 by authors and Scientific Research Publishing Inc.

This work is licensed under the Creative Commons Attribution International License (CC BY).

http://creativecommons.org/licenses/by/4.0/

(c) (i)

\section{Abstract}

The potential of biodiesel fuels from various vegetable oil sources such as sunflower (SFME), safflower (SAFME), peanut (PME) and canola (CME) as well as from low-cost chicken fat (CFME) to supplement increasing biodiesel demands must be evaluated in terms of the corresponding engine performance and exhaust emissions. In this study, two diesel engines rated at $14.2 \mathrm{~kW}$ (small) and $60 \mathrm{~kW}$ (large) were operated by using the different biodiesel fuels and a reference diesel. Results showed that both the small and large engines delivered similar power when using biodiesel fuels in the expense of higher brake-specific fuel consumptions (BSFC). Higher exhaust concentrations of nitrogen oxides $\left(\mathrm{NO}_{\mathrm{x}}\right)$ and carbon dioxide $\left(\mathrm{CO}_{2}\right)$ while lower carbon dioxide $(\mathrm{CO})$ and negligible sulfur dioxide $\left(\mathrm{SO}_{2}\right)$ emissions were observed in both engines. Total hydrocarbon emissions (THC) were higher in both engines when using SME, SFME and CME but comparable when using CFME, SAFME and PME in the large engine. Thus, with the increasing demand for biodiesel, alternative feedstock sources such as those used in this study may be utilized to take advantage of their availability, renewability and environmental benefits.

\section{Keywords}

Biodiesel, Vegetable Oil, Chicken Fat, Engine Performance, Exhaust Emissions

\footnotetext{
${ }^{*}$ Corresponding author.
}

How to cite this paper: Santos, B.S. and Capareda, S.C. (2015) A Comparative Study on the Engine Performance and Exhaust Emissions of Biodiesel from Various Vegetable Oils and Animal Fat. Journal of Sustainable Bioenergy Systems, 5, 89103. http://dx.doi.org/10.4236/jsbs.2015.53009 


\section{Introduction}

With the world's progress in making technological advancements, the increasing dependence on power generation using fuels comes, which for the time-being, are sourced mainly from fossil reserves. A technological advancement that shaped today's civilization is the use of compression-ignition (CI) or diesel engine, particularly in the transportation, automotive and agricultural sectors [1]. It was first developed in 1900 by Rudolph Diesel, who showed that it can be operated by using peanut oil [2], which, however, caused several problems because of its high viscosity and low volatility [3]. At that time, petroleum-based diesel fuel became the choice fuel for diesel engines due to its availability and abundant supply. However, petroleum-based fuels are now deemed to be depleting and found to have detrimental effects to the environment with their long-term use, and thus, the need for the utilization of fuels is required, which can be derived from renewable sources and which yields reduced levels of pollutants [4].

As demonstrated by Rudolph Diesel, oils from biomass can be a potential alternative to petroleum-based fuels but they need to be modified first to improve their properties. One method is through the transesterification of the oils to produce a mixture of monoalkyl esters of long chain fatty acids (FAME) termed as biodiesel [5]-[7]. Due to its very similar properties with petroleum-based diesel fuel [8] [9], biodiesel has been established as an alternative diesel engine fuel, which is further supported by the fact that it can be used in any compression ignition engine without major modification [10]. Additional benefits of biodiesel include: improved lubricity, higher flash point, lower toxicity, biodegradability, and no net contribution to the greenhouse effect because of its renewable sources [11].

The feedstock commonly utilized for biodiesel production depends upon the country's geographical, climatic and economic conditions. In the US, the main feedstock for biodiesel production is soybean oil [12]; however, its supply may not be enough to accommodate the projected increase in biodiesel demand. Soybean oil accounts for only $13.5 \%$ of the total biodiesel production [13] and only an estimated $6 \%$ of petroleum diesel demand can be replaced if all US soybean productions were utilized as biodiesel feedstock [14]. Consequently, other vegetable oils and animal fats were identified as alternative feedstocks, of which there are oils from sunflower, safflower, peanut and canola, as well as chicken fats. Table 1 lists the annual production of these feedstocks as reported by the USDA [15] as well as the oil content of each feedstock. Peanuts have the highest yield and oil content among the crops. Safflower, sunflower and soybean have comparable oil content while canola has similar oil content as with peanuts.

The use of sunflower seed is found in the food and nutraceutical industries due to its high oil and protein contents [20]. Recent studies on biodiesel production from sunflower oil vary from optimization of the transesterification process conditions, variation in catalysts, and blending with other oils prior to biodiesel production [21]-[24]. Safflower, on the other hand, is a drought-resistant oilseed, whose oil is flavorless and odorless and similar to sunflower oil in terms of nutritional value [25]. Studies on biodiesel production from safflower oil mainly involved parameter and optimization studies [26] [27].

Peanut is an important crop grown in the US and is widely cultivated in warm climates. It is used for oil production, peanut butter, confections and snacks products. Studies on peanut oil biodiesel production are rather limited [28]-[30]. Canola, on the other hand, is a variety of rapeseed with low erucic aid ( $<2 \%$ in the oil) and low levels of saturated fatty acids (6\%), high levels of monounsaturated fatty acid such as oleic acid (58\%) and

Table 1. Annual production yield and oil content data for different biodiesel feedstocks.

\begin{tabular}{cccc}
\hline Feedstock & Yield (metric tons per ha) $^{\mathrm{a}}$ & ${\text { Production }(1000)^{\mathrm{a}}}^{\mathrm{a}}$ & Oil content (\%) $^{\mathrm{b}}$ \\
\hline Canola & 1.59 & $2,447,410(\mathrm{lbs})$ & $40-45^{\mathrm{c}}$ \\
Peanuts & 4.70 & $6,741,400(\mathrm{lbs})$ & $45-55$ \\
Safflower & 1.26 & $179,424(\mathrm{lbs})$ & $15-34^{\mathrm{d}}$ \\
Soybean & 2.66 & $3,014,998(\mathrm{bu})$ & $25-35$ \\
Sunflower & 1.70 & $2,785,695(\mathrm{lbs})$ & - \\
\hline
\end{tabular}

a[15]; ${ }^{\mathrm{b}}[16] ;{ }^{\mathrm{c}}[17] ;{ }^{\mathrm{d}}[18] ;{ }^{\mathrm{e}}[19]$. 
moderate levels of polyunsaturated fatty acids (36\%) [31]. Some advantages of using canola oil are: it has high oxidation stability, can produce better quality biodiesel [32] and has a high ratio of unsaturated to saturated fatty acids, giving it a low value of liquefaction temperature $\left(3^{\circ} \mathrm{C}-4^{\circ} \mathrm{C}\right)$ which is beneficial in terms of preventing engine blockage [33].

Chicken fat is a relatively inexpensive by-product in the poultry industry [1] obtained from the extraction from feather meal prepared from chicken wastes such as chicken feathers, blood, offal, and trims after the rendering process during chicken processing [34]. A few researchers have investigated conversion of chicken fat into biodiesel [34]-[37].

One important aspect in biodiesel research that must be considered is the assessment of its performance as an engine fuel. There have been a number of literatures that discussed biodiesel performance in an engine specifically the effect of using biodiesel blends on engine power and fuel economy [38]. Biodiesel produced from different oil sources has been employed in a variety of engine configurations. However, variation in the quality of the biodiesel caused by differences in the esterification process and the raw materials used, among others, may affect engine performance [39].

Aside from engine testing, emissions associated with the use of biodiesel also need to be evaluated to assess its cleanliness as a fuel. The Environmental Protection Agency (EPA) reported that non-road diesel engines have a substantial role in contributing to the nation's air pollution and therefore stricter emission standards were imposed with regards to the amounts of particulate matter, nitrogen oxides and sulfur oxides [40]. This necessitates the analysis of biodiesel emissions to ensure compliance with current EPA regulations.

Thus, this paper aims to investigate the performance and emissions characteristics of two stationary non-road farm diesel engines operated on different biodiesels produced by using various vegetable oil sources such as sunflower, safflower, peanut and canola as well as chicken fat, and compare them with soybean oil biodiesel and a reference diesel. Specifically, this study aims to: 1) assess fuel properties of the different biodiesels in accordance with ASTM standards; 2) determine the effect of the biodiesel feedstock on the characteristic engine performance (i.e. net brake power, torque and specific consumption); and 3) compare the exhaust pollutant concentrations (i.e. $\mathrm{NO}_{\mathrm{x}}$, THC, $\mathrm{CO}$ and $\mathrm{CO}_{2}$ ) when using the different test fuels.

\section{Materials and Methods}

\subsection{Materials}

Sunflower oil biodiesel (SFME), safflower oil biodiesel (SAFME) and peanut oil biodiesel (PME) were prepared from previously extracted and refined oils at the Bio-Energy Testing and Analysis (BETA) Laboratory at Texas A\&M University, College Station, TX. Based on preliminary studies, the following conventional biodiesel reaction conditions were used: reaction time, $1 \mathrm{~h}$; weight of catalyst, $0.4 \%$ wt. of initial oil weight; vol. of methanol, $15 \%$ vol. of oil; reaction temperature: $50^{\circ} \mathrm{C}$.

Canola oil biodiesel (CME), chicken fat biodiesel (CFME), soybean oil biodiesel (SME) and the ultra-low sulfur diesel standard no. 2 reference fuel (REFDIESEL) were obtained from commercial producers (New Energy Fuels, Waller, TX; Gulf Hydrocarbon, Inc., Houston, TX; Producer’s Cooperative, Bryan, TX).

\subsection{ASTM Characterization of Biodiesel Fuels}

ASTM characterization of the biodiesel was done to ensure that the test fuel used in the study conforms to the ASTM D6751-08 standard (ASTM, 2008). Some of the referenced procedures in the ASTM 6751 standard were conducted in the BETA lab. Such procedures were: cloud and pour point (Koehler Instrument Company, Inc., Houston, TX; ASTM D2500), flash point (Koehler Instrument Company, Inc., Houston, TX; ASTM D93), water and sediment (Sigma Zentrifugen, Germany; ASTM D2709), kinematic viscosity (Koehler Instrument Company, Inc., Houston, TX; ASTM D445), acid number (Cole-Parmer Instrument Company, LLC, IL; ASTM D664) and gross heating value (Parr Instrument Company, Moline, IL; ASTM D4809).

\subsection{Engine Performance and Exhaust Emissions Testing}

Engine performance and exhaust emissions testing were conducted at the BETA Lab engine testing facility. Test engines, instrumentation and data acquisition equipment used were discussed in a previous study [41]. 


\subsubsection{Experimental Method}

Engine power tests are conducted in accordance with SAE Standard Engine Power Test Code for diesel engines (SAE J1349 Revised MAR2008). Baseline engine performance and emissions tests are performed using ULSD reference diesel fuel. Engine performance data for ULSD reference diesel were corrected to the standard atmospheric conditions using the compression ignition engine correction formula according to SAE J 1349-MARCH 2008.

Variables such as air and relative humidity are carefully monitored. Fuel temperature is controlled as outlined in the test procedure. Tests were conducted in a randomized complete block design (RCBD) to prove that the fuel sequence is not significant to the results of the study. Response variables were the following: net brake power $(\mathrm{kW})$, torque $(\mathrm{N}-\mathrm{m})$, fuel consumption $(\mathrm{L} / \mathrm{h}), \mathrm{NO}_{\mathrm{x}}$ concentrations $(\mathrm{ppm})$, unburned hydrocarbon concentrations (ppm), $\mathrm{CO}$ concentrations (ppm), and $\mathrm{CO}_{2}$ concentrations (\%).

The BETA lab is equipped with a NI Labview program that can perform remote-based switching of fuel source. This provides changing of test fuels without turning off the engine. At each fuel change, the fuel filter was replaced and then the engine was warmed at idle speed on the new fuel for 15 minutes to purge remaining previous test fuel from the engine's fuel system. Then, the engine was operated at full throttle and prepared for the next performance testing. Also, a new set of sintered filters for the exhaust emissions analyzer was installed prior to the next emissions testing.

The important sources of uncertainty in this study are: 1) supply of consistent quality of fuel, 2) proper control over relevant engine parameters (e.g. speed and load), and 3) proper use and calibration of the measurement instruments. To minimize the first source of uncertainty, test fuels were processed in such a way that it will match up ASTM 6751 standard. Fresh batch of biodiesel was used to ensure consistency of the fuel quality in the experiment. Having proper control and use of engine instrumentation and controller equipment minimized uncertainty associated with the second source. Parameters, such as engine speed, fuel flow rate, and load accuracy were matched to within \pm 5 RPM, $\pm 1 \%$ of the reading, and $\pm 0.05 \%$ of the rated output, respectively. Finally, uncertainty associated with the third source was minimized through routine calibration of emissions equipment and all other instruments (e.g. pressure transducers, thermocouples, flow rate meters, etc.) prior to start of testing.

In order to understand the effect of the biodiesel on engine combustion efficiency, the brake specific fuel consumptions (BSFC) for the test fuels were measured at peak torque condition. This condition was chosen since it is the point of minimum air/fuel ratio and maximum smoke [7]. Results were compared to those of the control fuel using statistical analysis procedures (Analysis of Variance and Fisher's Least Significant Difference Test).

\section{Results and Discussion}

\subsection{Characteristics of Test Fuels}

The different biodiesel and reference diesel were characterized to ensure that they meet certain standards established to guarantee successful engine performance. Some of the physico-chemical properties that were determined include: gross heating value, kinematic viscosity, cloud point, flash point, acid number, and water and sediment concentration, all according to published ASTM standards. Results are shown in Table 2, which also lists the specified limits in the standards for the different properties.

Flash point is the temperature at which a fuel will ignite upon exposure to a flame or spark and is inversely related to the fuel's volatility [6]. The minimum value stated in the standards is $130^{\circ} \mathrm{C}$ and all the biodiesel meet this requirement. The values are even higher than that for the reference diesel, which is indicative of a good fuel quality in terms of safety during transport, handling and storage [6].

Water and sediment need to be quantified in a fuel since they can be a source of various problems associated with fuel storage as well as engine operation due to corrosion and plugging [6]. All biodiesel fuels were below the standard specified limit of 0.05 vol\%. Water in biodiesel may occur either as dissolved or suspended water droplets while the sediment consists of suspended rust and dirt particles or insoluble compounds formed during fuel oxidation. Water in the biodiesel should be avoided since it may become acidic during storage and therefore cause corrosion of the engine components and storage tanks. It can also contribute to microbial growth during storage. Sludge and slimes may be produced by these microorganisms, which can cause filter plugging. In addition, hydrolysis reactions can proceed with the high water content, thus, converting biodiesel to free fatty acids, 
Table 2. Properties of test fuels and the reference diesel according to ASTM standards.

\begin{tabular}{|c|c|c|c|c|c|c|c|c|c|}
\hline Property & Method & Specifications & $\begin{array}{l}\text { Reference } \\
\text { Diesel }\end{array}$ & $\begin{array}{l}\text { Soybean } \\
\text { ME }\end{array}$ & $\begin{array}{l}\text { Sunflower } \\
\text { ME }\end{array}$ & $\begin{array}{l}\text { Safflower } \\
\text { ME }\end{array}$ & Peanut ME & Canola ME & $\begin{array}{l}\text { Chicken } \\
\text { Fat ME }\end{array}$ \\
\hline Flash Point, ${ }^{\circ} \mathrm{C}$ & D93 & 130 min. & 128 & 199 & 192 & 197 & 190 & 171 & 131 \\
\hline Water and Sediment, \%vol & D2709 & 0.050 max. & $<0.01$ & $<0.01$ & $<0.01$ & $<0.01$ & $<0.05$ & $<0.01$ & $<0.05$ \\
\hline $\begin{array}{c}\text { Kinematic Viscosity, } 40^{\circ} \mathrm{C}, \\
\mathrm{mm}^{2} / \mathrm{s}\end{array}$ & D445 & $1.9-6.0$ & 2.3 & 4.7 & 6.3 & 5.5 & 7 & 4.8 & 4.7 \\
\hline Sulfur, ppm & D5453 & 15 max. & Unknown & 4 & Unknown & Unknown & Unknown & Unknown & $<0.001$ \\
\hline Cetane Number & D613 & $47 \mathrm{~min}$. & Unknown & 55 & Unknown & Unknown & Unknown & Unknown & 48.2 \\
\hline Cloud Point, ${ }^{\circ} \mathrm{C}$ & D2500 & Report & -35 & -6 & 2 & 2 & 15 & -5 & 7 \\
\hline Carbon Residue, \%mass & D4530 & 0.050 max. & Unknown & 0.01 & Unknown & Unknown & Unknown & Unknown & 0.02 \\
\hline $\begin{array}{c}\text { Acid Number, mg KOH/g } \\
\text { sample }\end{array}$ & D664 & 0.50 max. & 0.04 & 0.19 & Unknown & 0.68 & 0.13 & 0.2 & 0.14 \\
\hline Distillation Temperature, ${ }^{\circ} \mathrm{C}$ & D1160 & 360 max. & Unknown & 329 & Unknown & Unknown & Unknown & Unknown & 352 \\
\hline Oxidation Stability, hours & EN14112 & 3 min. & Unknown & 7.2 & Unknown & Unknown & Unknown & Unknown & 3.3 \\
\hline $\begin{array}{l}\text { Gross Heating Value, } \\
\text { MJ/kg }\end{array}$ & D4809 & Report & 42.7 & 38.8 & 38.2 & 38.1 & 39.2 & 38.5 & \\
\hline
\end{tabular}

which can form fuel filter blockage [5].

Viscosity is an important fuel property since it indicates the ability of a material to flow and therefore affects the operation of fuel injection especially at low temperatures. The kinematic viscosities of the different biodiesels fall within the specified standard except for SFME and PME slightly exceeds the maximum standard value by around $5 \%$ and $17 \%$, respectively. The kinematic viscosities were also higher when compared to the reference diesel since biodiesel contains compounds with large molecular weights and chemical structures than those present in petroleum diesel [6].

The fuel's behavior at low temperatures should also be considered since partially or fully solidified fuel may result in blockage of the fuel lines and filters and thus, cause fuel starvation and eventually problems in engine operation and possible engine damage [7]. Thus, temperature parameters were established to identify the point when possible fuel solidification may occur. Cloud point is defined as the temperature at which the wax crystals in the fuel become visible when it is cooled. The biodiesels in this study have higher cloud points as compared with the reference diesel. Thus, problems in cold weather operation should be addressed for these biodiesel products.

Another important property of biodiesel is the acid number, which is merely the amount of free fatty acids (FFAs) present in the samples. These are either saturated or unsaturated monocarboxylic acids that occur naturally in fats, oils or greases, but are not attached to glycerol backbones. The biodiesels have acid numbers below the maximum standard value except for SAFME. High acid value in the fuel should be avoided since it may result in severe corrosion in the fuel supply system of the engine [6].

The energy content of the fuels was also determined and reported as the gross heating value in Table 1 . It is basically the amount of heat energy released by the combustion of a unit value of a fuel and also termed as the heat of combustion. There is no specified value in the ASTM standard but according to EN 14213 (biodiesel for heating purposes), the minimum value is $35 \mathrm{MJ} / \mathrm{kg}$. The heating values of the different biodiesel pass this standard although they are lower as compared with the heating value of the reference diesel.

These differences in the fuel properties of the various biodiesel used in this study can lead to differences in engine performance and exhaust emissions, as will be discussed in the succeeding paragraphs.

\subsection{Engine Performance}

The performances of the engines at full load (the fuel pump is at the maximum delivery setting) were determined in accordance to SAE J1349 Power test code procedures. Baseline engine performance and emissions tests were performed using standard no. 2 ULSD fuel (REFDIESEL). Corrected values of the net brake power 
and brake-specific fuel consumption for ULSD, as described earlier, were also presented in the following sections.

\subsubsection{Net Brake Power}

1) Small engine

The net brake power at different engine speeds and test fuels are presented in Figure 1. At different engine speeds, there is an initial gradually increasing trend in power until a maximum is reached and then it falls rapidly as the engine speed is further increased. Power decreases after a maximum is reached due to increase in friction at higher speeds. The net brake power, as defined by the Society of Automotive Engineers [42], is a measure of the engine's horsepower delivered directly to the engine's crankshaft without the loss in power caused by the accessories such as the gearbox, alternator, differential, water pump, and other auxiliary components such as power steering pump, muffled exhaust system, etc.

As observed in Figure 1, the corrected peak brake power for REFDIESEL is at $13.5 \mathrm{~kW}$ (18.0 hp) at an engine speed of approximately $2940 \mathrm{rpm}$. Similar results were obtained using B100 SME. The net brake power for B100 PME was only 2\% higher than REFDIESEL with $13.7 \mathrm{~kW}$. Other test fuels (i.e. B100 CME and B100 SFME) are $1 \%$ lower than REFDIESEL with both fuels obtaining $13.3 \mathrm{~kW}$. This negligible loss in power was also observed by Lin et al. [43], who observed that the maximum differences in engine power at full load between petroleum diesel and eight kinds of vegetable oil methyl esters is only about $1.49 \%$. They attributed this to the higher viscosity, fuel consumption, oxygen content and combustion rate of biodiesel. Also, Qi et al. [44] reported the same trend and explained that since engines deliver fuel on a volumetric basis, the higher density of biodiesel as compared to diesel implies more fuel is delivered and this compensates for the lower heating value of biodiesel, thus yielding negligible power loss in comparison with petroleum diesel. Others also reported that insignificant changes in engine power can be obtained even when using different feedstocks such as waste palm oil and canola oil methyl esters [45] and soybean, rapeseed and palm oil biodiesels on a 3-cylinder, 4-stroke, 30-kW diesel engine [46].

2) Large engine

For the 4-cylinder-80-hp John Deere engine, the net brake power at different engine speeds as shown in Figure 2 follows the same trend as with the small engine. The corrected peak net brake power using REFDIESEL was observed to be the highest compared to the biodiesel fuels. Percent differences in peak net brake power were from $0.2 \%$ to $2 \%$. Similar explanations as with the small engine can be applied to these observations.

\subsubsection{Engine Torque}

The engine torque at varying engine speed and fuel blends for the large engine were also obtained and shown in Figure 3. The torque is a good indicator of an engine's ability to do work and is a function of engine speed. Similar to engine power, the torque was gradually increasing at low speed and decreased rapidly after a maximum

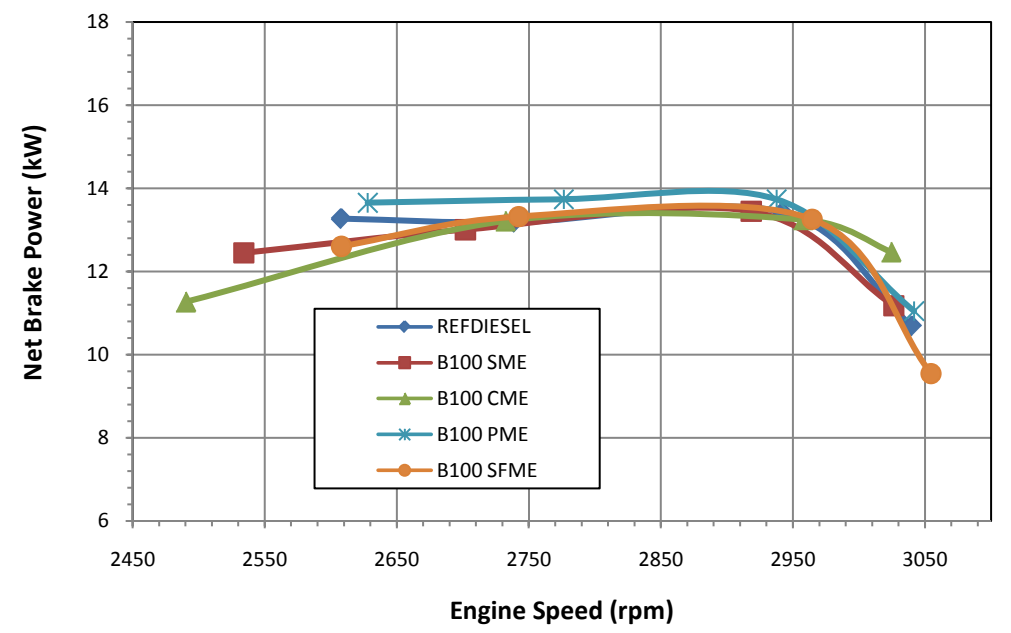

Figure 1. Net brake power of the Yanmar engine using different test fuels at varying engine speed. 


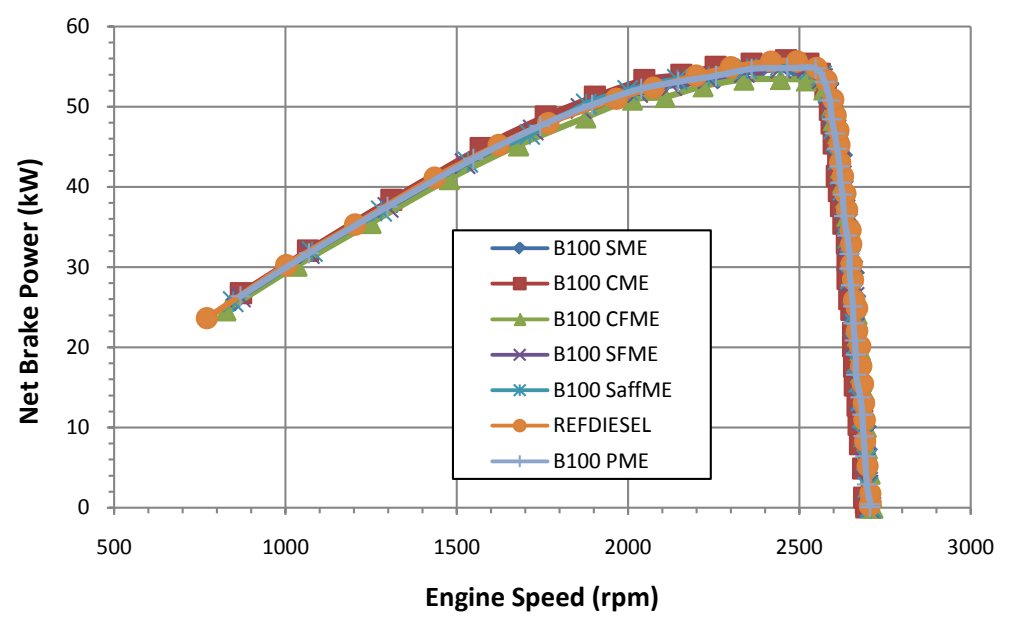

Figure 2. Net brake power of the John Deere engine using different test fuels at varying engine speed.

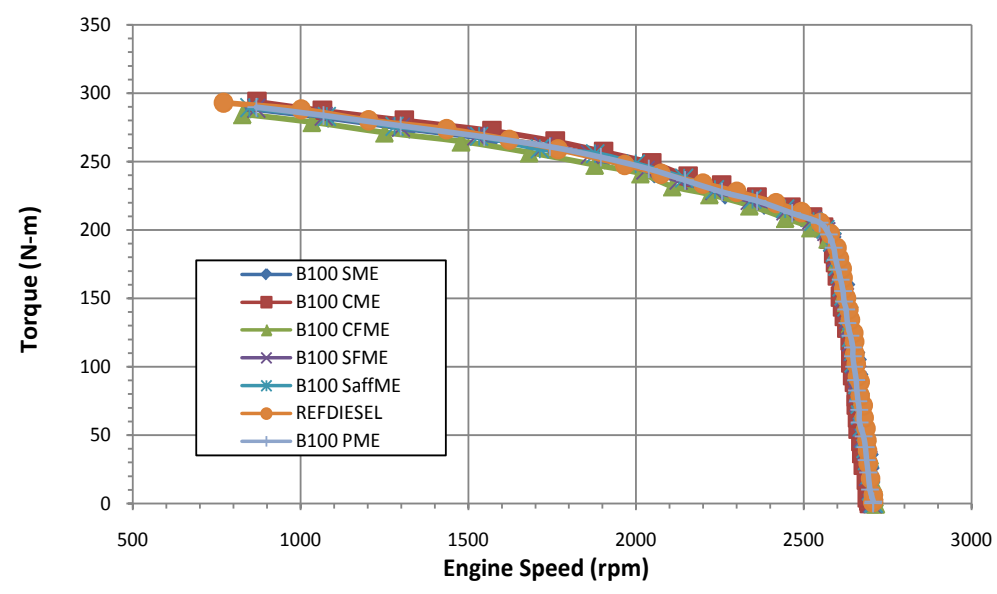

Figure 3. Engine torque of the John Deere engine using different test fuels at varying engine speed.

value was reached. Torque decreases because the engine is unable to ingest a full charge of air at higher speeds [47].

Moreover, the peak torque value for REFDIESEL was higher than peak torque values for biodiesel fuels, except for CME, which has similar peak torque value as with REFDIESEL. The highest decrease in peak torque value was observed for CFME, corresponding to a $2.9 \%$ decrease from $293.2 \mathrm{~N}-\mathrm{m}$ at $770.3 \mathrm{rpm}$ for REFDIESEL $284.8 \mathrm{~N}-\mathrm{m}$ at $825.5 \mathrm{rpm}$ for CFME. The other test fuels have peak torque values that are $1.2 \%-1.5 \%$ lower than REFDIESEL. The different biodiesel fuels performed similarly with the reference diesel.

\subsubsection{Brake Specific Fuel Consumption (BSFC)}

\section{1) Small engine}

The brake specific fuel consumption (BSFC) is a measure of fuel efficiency within the crankshaft of an internal combustion engine and can be obtained by dividing the rate of fuel consumption of the engine by the net brake power [47]. Figure 4 shows the BSFC in relation to varying engine speed and fuel blends for the Yanmar engine. The BSFC is observed to decrease with an increase in engine speed until it reaches a minimum value and further increases at higher speeds. Greater friction losses at higher speeds contribute to the increase in fuel consumption while at low speed, the longer time per cycle results in higher heat loss, allowing for more fuel consumption.

Using analysis of variance, at peak torque conditions, the BSFC's for all biodiesel fuels as compared to the 


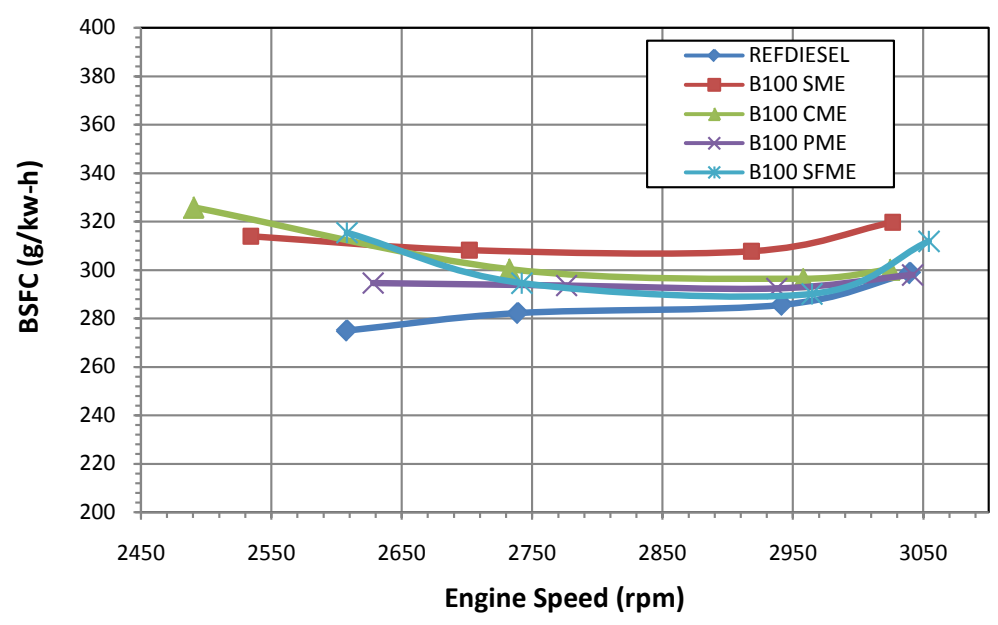

Figure 4. BSFC of the Yanmar engine using different test fuels at varying engine speed.

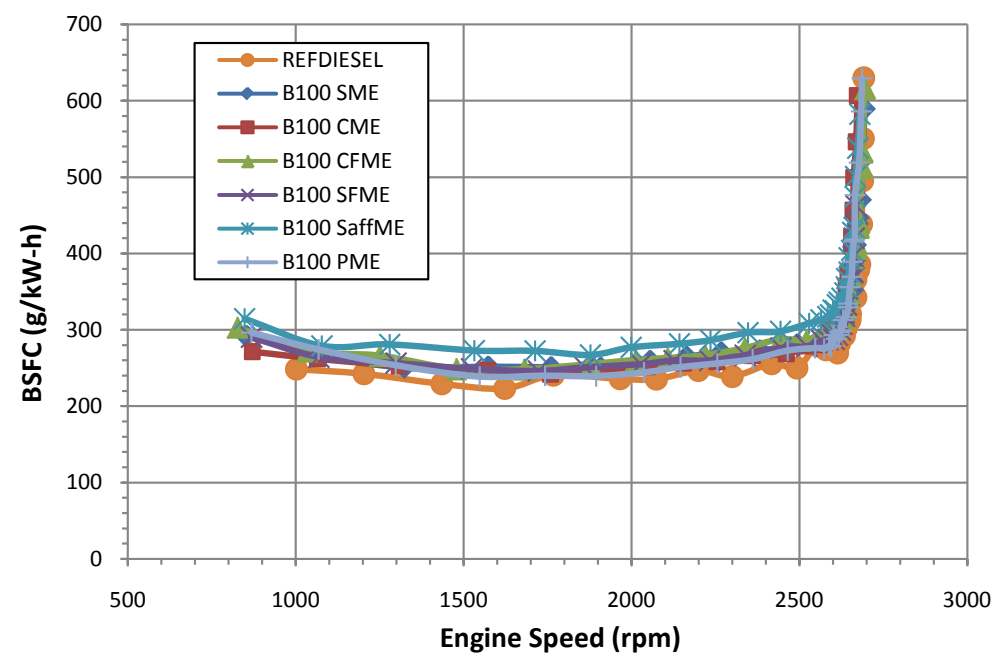

Figure 5. BSFC of the John Deere engine using different test fuels at varying engine speed.

reference fuel has increased significantly, with 14\%, 10\%, 9\%, and 5\% increase for SME, CME, PME and SFME, respectively. An increase in BSFC was also observed by Moreno et al. [39], when they fueled a fourcylinder, turbocharged, indirect injected Isuzu engine with pure sunflower oil biodiesel. The BSFC increased by approximately $12 \%$ higher than with pure diesel fuel. Kaplan et al. [48] also observed similar results. The observed increase in fuel consumption when using biodiesel can be attributed to the combined effects of the biodiesel properties such as lower heating value and higher density and viscosity as compared to a regular diesel [38] [49]. The higher density of biodiesel indicates that higher mass is injected for the same volume at the same injection pressure while the lower calorific or heating value indicates that a larger quantity of fuel must be injected into the combustion chamber to produce the same power, thus leading to an increase in the specific fuel consumption [49].

2) Large engine

Figure 5 shows the BSFC at different engine speeds when running the large John Deere engine with the different biodiesel fuels and reference diesel. Higher BSFC was again obtained for REFDIESEL as compared with the biodiesel fuels. Using analysis of variance, at peak torque conditions, SaffME obtained the highest BSFC with $314.8 \mathrm{~g} / \mathrm{kW}$-h, while REFDIESEL obtained the lowest with $248.8 \mathrm{~g} / \mathrm{kW}$-h. Similar explanation as with the small engine can be applied in these observations. On the other hand, Fisher's least significant difference test 
indicated that there is no strong evidence of differences among SME, SFME and PME test fuels.

Also, it is interesting to note that the large engine had relatively lower BSFC values than the small engine. BSFC values range from 267 - $308 \mathrm{~g} / \mathrm{kW}$-h for the small engine while it ranges from 248 - $278 \mathrm{~g} / \mathrm{kW}$ - $\mathrm{h}$ for the large engine. According to Pulkrabek [47], BSFC generally decreases with engine size, being best (lowest) for very large engines. One reason for this is that large engines have less heat loss due to the higher volume-to-surface-area ratio of its combustion chamber. Also, larger engines operate at lower speeds, which reduce friction losses.

\subsection{Exhaust Emissions}

Since the composition of the fuel affects the emissions of an engine, emissions from biodiesel fuel are also different as compared to those of petroleum diesel. Due to its higher oxygen content ( $10-12 \mathrm{wt} \%$ ), biodiesel has less heating value and yields less particle emissions. Additional advantage is the absence of sulfur in biodiesel, thus removing the typical aerosols derived from sulfuric acid formed during diesel fuel combustion. However, it should be noted that the results can also be affected by the type of engine and its condition [50]. Some of the EPA regulated emissions determined in this research were $\mathrm{CO}, \mathrm{CO}_{2}, \mathrm{NO}_{\mathrm{x}}, \mathrm{SO}_{2}$, and total hydrocarbons.

\subsubsection{Small Engine Emissions}

Exhaust emissions of the Yanmar 3009D test engine using the different test fuels are shown in Figure 6. In general, all biodiesel fuels under study have higher $\mathrm{NO}_{\mathrm{x}}$ concentrations than the reference fuel. The same was observed by many other researchers concerning the $\mathrm{NO}_{\mathrm{x}}$ emissions when using biodiesel. A maximum of $15 \%$ increase in $\mathrm{NO}_{\mathrm{x}}$ emissions for $\mathrm{B} 100$ was observed by Nabi et al. [51] at high load condition which was attributed to the $12 \%$ oxygen content of the B100 and higher gas temperature in combustion chamber. A greater increase in $\mathrm{NO}_{\mathrm{x}}$ emissions (22.1\%) was observed by Ozsezen et al. [45] when they employed waste palm oil biodiesel on a 6-cylinder WC, NA, DI diesel engine while canola biodiesel produced $\mathrm{NO}_{\mathrm{x}}$ emissions higher than petrodiesel by $6.5 \%$. The increase in $\mathrm{NO}_{\mathrm{x}}$ emissions could have been affected by the differences in the fuel properties between diesel and biodiesel. According to Moser et al. [52], the higher density and viscosity of the biodiesel imply that the differential pressure at the advance piston contained in the distributor pump is slightly increased, which in turn advances injection. Also, the amount of fuel injected per cycle could also be affected by variations in density in the fuel. In addition, the fuel spray properties might also be modified due to increases in the size of the droplets of the fuel, thus affecting burning of the fuel [52]. The increase in $\mathrm{NO}_{\mathrm{x}}$ emissions could also be related to the higher oxygen content of biodiesel, as it may provide additional oxygen for $\mathrm{NO}_{\mathrm{x}}$ formation [53] .

The CO emissions, on the other hand, decreased as the engine speed increased and were lower for the biodiesel fuels in comparison with the reference diesel. Puhan et al. [54] also observed a decrease of around 30\% in CO emissions when they used Mahua oil biodiesel instead of petroleum diesel. Utlu et al. [55] observed a 17.1\% decrease when using waste frying oil biodiesel and Wu et al. [56] reports an average of $4 \%-16 \%$ CO reduction for five biodiesels. The lower CO emissions can be attributed to the higher oxygen content of biodiesel as compared to petroleum diesel, which promotes complete combustion and thus, reduction in CO emissions [57]-[60].

$\mathrm{CO}_{2}$ emissions followed the same trend as $\mathrm{CO}$ emissions with respect to engine speed but were found to be higher for the biodiesel fuels as compared with the reference diesel. Other researchers also report that the $\mathrm{CO}_{2}$ emissions increase when an engine is ran on biodiesel due to more efficient combustion [57] [61]-[65]. Nevertheless, others reason out that this can be offset by planting and raising biodiesel crops as supported by life-cycle assessment of $\mathrm{CO}_{2}$ emissions from biodiesel [65] [66]. About 50\% - 80\% reduction in $\mathrm{CO}_{2}$ emissions can be obtained when using biodiesel [67].

The emissions of THC, on the other hand, seemed to be not affected by the engine speed and were found to be higher for the biodiesel fuels; with comparable for SME, PME and CME test fuels but higher value for SFME. A similar increase in hydrocarbon emissions was observed by Muñoz et al. [50] at high engine speed and load. They explained that hydrocarbon emissions increased since the higher density and viscosity of biodiesel changes the characteristics of the fuel jet, i.e. size of droplets, penetration, etc., liberated by the injector. It also increases the amount of fuel retained in the interior of the injector nozzle, and therefore cannot be incorporated in the combustion chamber immediately, causing an increase in the hydrocarbons without burning.

Lastly, negligible $\mathrm{SO}_{2}$ concentrations were lower for PME as compared with REFDIESEL, a proof of obtaining lower sulfur emissions when using biodiesel rather than petroleum diesel. 

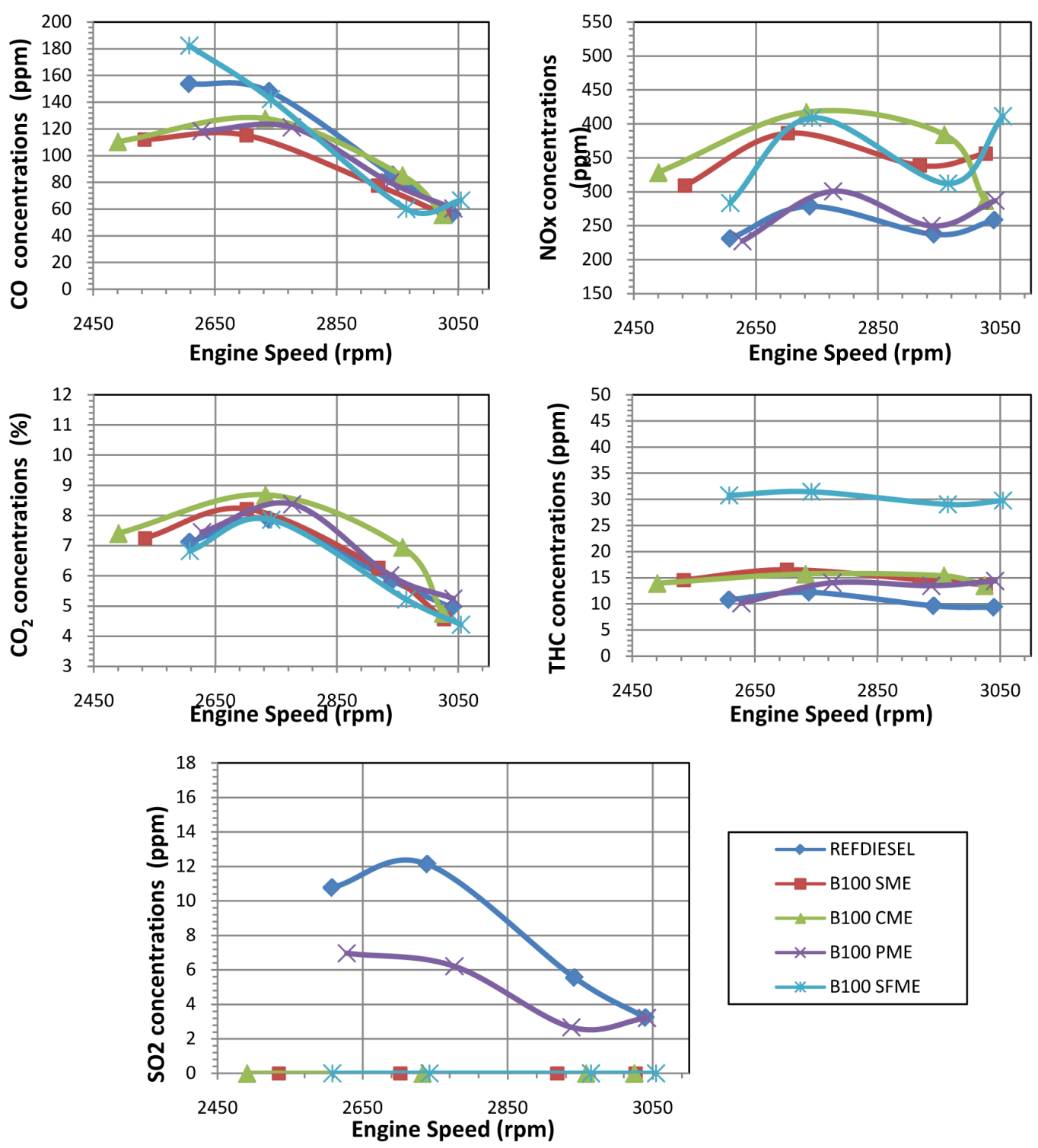

Figure 6. Various emission concentrations of the Yanmar engine using different test fuels at varying engine speed.

\subsubsection{Large Engine Emissions}

The emissions of the large John-Deere engine using different test fuels are shown in Figure 7. Similar to the small engine emissions, $\mathrm{NO}_{\mathrm{x}}$ concentrations tend to decrease as the speed of the engine is increased. Also, REFDIESEL obtained the lowest peak $\mathrm{NO}_{\mathrm{x}}$ concentrations with $454 \mathrm{ppm}$ at $1203 \mathrm{rpm}$. Highest $\mathrm{NO}_{\mathrm{x}}$ emissions at peak torque conditions were observed for $\mathrm{CME}$ at $38 \%$ increase, corresponding to $\mathrm{NO}_{\mathrm{x}}$ concentrations of 627 $\mathrm{ppm}$. This increase can be explained by the reasons described earlier for the small engine.

$\mathrm{CO}_{2}$ concentrations were observed to gradually increase as the speed was increased up to a certain point (2050 rpm) only and then decreased rapidly up to peak power conditions. $\mathrm{CO}_{2}$ emissions were higher for $\mathrm{CME}$ as compared with those of SME and REFDIESEL at the given range of engine speed. At peak torque conditions, CME has around $17.5 \%$ higher $\mathrm{CO}_{2}$ emissions than SME. SME and REFDIESEL have comparable $\mathrm{CO}_{2}$ emissions while the other biodiesel fuels have slightly higher emissions than REFDIESEL.

$\mathrm{CO}$, THC and $\mathrm{SO}_{2}$ concentrations, on the other hand, tend to peak as they approach peak power conditions. Similar to the small engine, there was a reduction in $\mathrm{CO}$ emissions when using the biodiesel fuels than the reference diesel, which yielded 138 ppm CO emission at peak torque conditions. THC emissions, on the other hand, 

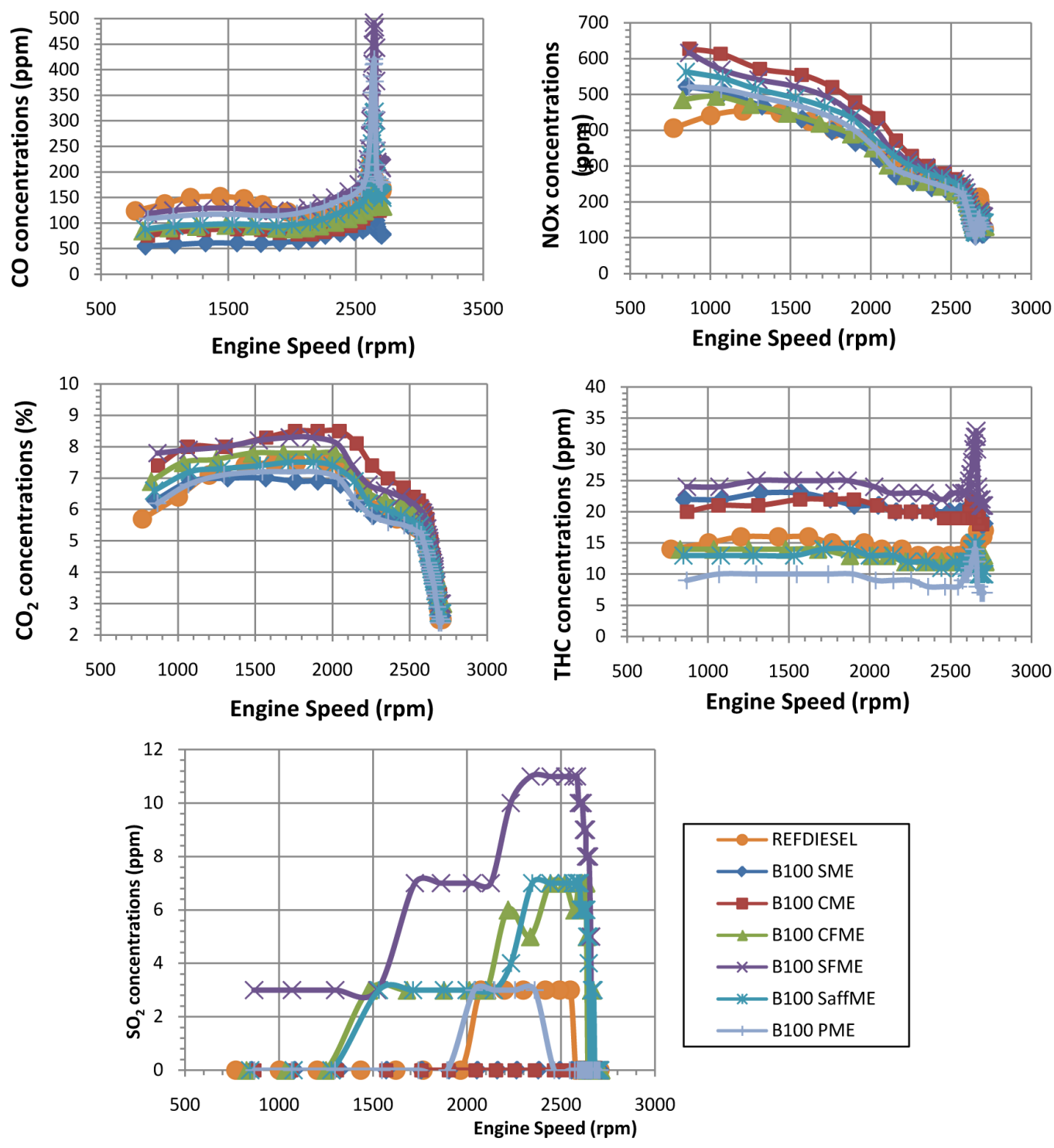

Figure 7. Various exhaust emissions of the John Deere engine using different test fuels at varying engine speed.

were higher by around 33\% - 47\% for CME, SME and SFME as compared to REFDIESEL, but slightly lower, if not comparable, for CFME, SAFME and PME. Finally, negligible $\mathrm{SO}_{2}$ emissions were obtained for all test fuels at peak torque conditions.

\section{Summary and Conclusions}

In summary, very few losses (up to $2 \%$ ) in power and torque were observed when running both the small and large engines with biodiesel fuels rather than the reference diesel. Power is a function of the engine geometry, speed, air/fuel ratio, efficiencies and fuel properties. Assuming that mechanical losses were similar, and since there were no modifications made in the injection rates or duration for an individual test fuel, similar engine performance for the biodiesel fuels in comparison with the reference diesel indicates that even though the heating values of the biodiesel fuels were lower as compared to that for the reference diesel, the same power and torque were delivered due to the increased fuel consumption. Indeed, BSFC values at peak torque conditions for both engines were higher when using the biodiesel fuels rather than the reference diesel.

For the exhaust emissions, higher $\mathrm{NO}_{\mathrm{x}}$ concentrations were obtained in both the small and large engines when 
using the biodiesel fuels. Also, both engines yielded lower $\mathrm{CO}$ but higher $\mathrm{CO}_{2}$ emissions, owing to better combustion characteristics imparted by the higher oxygen content of the biodiesel fuels as compared to the reference diesel. Also, THC increased while $\mathrm{SO}_{2}$ emissions were negligible. Differences in exhaust emission concentrations in the biodiesel fuels and reference diesel were observed due to changes in properties such as density, viscosity and heating values, as well as the composition of the fuel. These altogether affect the fuel injection characteristics and the mechanism of fuel burning, thus resulting in variation in emission concentrations of the EPA regulated pollutants. Thus, biodiesel from the different vegetable oils and chicken fat used in this study proved their potential as petroleum diesel substitute in terms of delivering similar engine performance and yielding lower $\mathrm{CO}$ and $\mathrm{SO}_{2}$ emissions.

\section{Acknowledgements}

The authors would like to thank Houston Advanced Research Center, Texas A\&M Agrilife Research and BioEnergy Testing and Analysis (BETA) Laboratory for the support of this study.

\section{References}

[1] Gumus, M., Sayin, C. and Canacki, M. (2010) Effect of Fuel Injection Timing on the Injection, Combustion, and Performance Characteristics of a Direct-Injection (DI) Diesel Engine Fueled with Canola Oil Methyl Ester-Diesel Fuel Blends. Energy Fuels, 24, 3199-3213. http://dx.doi.org/10.1021/ef9014247

[2] McCarthy, P., Rasul, M.G. and Moazzem, S. (2011) Analysis and Comparison of Performance and Emissions of an Internal Combustion Engine Fuelled with Petroleum Diesel and Different Bio-Diesels. Fuel, 90, 2147-2157. http://dx.doi.org/10.1016/j.fuel.2011.02.010

[3] Isigigur, A., Karaosmanoglu, F., Aksoy, H.A., Hamdullahpur, F. and Gulder, O.L. (1994) Performance and Emission Characteristics of a Diesel Engine Operating on Safflower Seed Oil Methyl Ester. Applied Biochemistry and Biotechnology, 45/46, 93-102. http://dx.doi.org/10.1007/BF02941790

[4] Kocak, M.S., Ileri, E. and Utlu, Z. (2007) Experimental Study of Emission Parameters of Biodiesel Fuels Obtained from Canola, Hazelnut, and Waste Cooking Oils. Energy Fuels, 21, 3622-3626. http://dx.doi.org/10.1021/ef0600558

[5] Demirbas, A. (2009) Progress and Recent Trends in Biodiesel Fuels. Energy Conversion and Management, 50, 14-34. http://dx.doi.org/10.1016/j.enconman.2008.09.001

[6] Atabani, A.E., Silitonga, A.S., Badruddin, I.A., Mahalia, T.M.I., Masjuki, H.H. and Mekhilef, S. (2012) A Comprehensive Review on Biodiesel as an Alternative Energy Resource and Its Characteristics. Renewable \& Sustainable Energy Reviews, 16, 2070-2093. http://dx.doi.org/10.1016/j.rser.2012.01.003

[7] Canacki, M. and Van Gerpen, J. (2001) Biodiesel Production from Oils and Fats with High Free Fatty Acids. Transactions of the ASABE, 44, 1429-1436.

[8] Alptekin, E. and Canacki, M. (2009) Characterization of the Key Fuel Properties of Methyl Ester-Diesel Fuel Blends. Fuel, 88, 75-80. http://dx.doi.org/10.1016/j.fuel.2008.05.023

[9] Kinast, A.J. (2001) Production of Biodiesels from Multiple Feedstocks and Properties of Biodiesels and Biodiesel-Diesel Blends. National Renewable Energy Laboratory, Golden. http://www.biofuels.coop/archive/biodiesel_report.pdf

[10] National Bio-Diesel Board (2009) What Is Bio-Diesel? http://biodiesel.org/docs/ffs-basics/benefits-of-biodiesel.pdf?sfvrsn=4

[11] Wyatt, V.T., Hess, M.A., Dunn, R.O., Foglia, T.A., Haas, M.J. and Marmer, W.N. (2005) Fuel Properties and Nitrogen Oxide Emission Levels of Biodiesel Produced from Animal Fats. Journal of the American Oil Chemists' Society, 82, 585-591. http://dx.doi.org/10.1007/s11746-005-1113-2

[12] Moser, B.R. (2009) Biodiesel Production, Properties, and Feedstocks. In Vitro Cellular \& Developmental BiologyPlant, 45, 229-266. http://dx.doi.org/10.1007/s11627-009-9204-z

[13] USDA (2013) US Bioenergy Statistics. http://www.ers.usda.gov/data-products/us-bioenergy-statistics.aspx

[14] Hill, J., Nelson, E., Tilman, D., Polasky, S. and Tiffany, D. (2006) Environmental, Economic, and Energetic Costs and Benefits of Biodiesel and Ethanol Biofuels. Proceedings of the National Academy of Sciences of the United States of America, 103, 11206-11210. http://dx.doi.org/10.1073/pnas.0604600103

[15] USDA (2013) US Crop Production Data. National Agricultural Statistics Service (NASS), Agricultural Statistics Board, United States Department of Agriculture (USDA).

[16] Karmakar, A., Karmakar, S. and Mukherjee, S. (2010) Properties of Various Plants and Animals Feedstocks for Biodiesel Production. Bioresource Technology, 101, 7201-7210. http://dx.doi.org/10.1016/j.biortech.2010.04.079 
[17] O’Brien, R., Farr, W. and Wan, P. (2000) Introduction to Fats and Oils Technology. 2nd Edition, AOCS Press, Champaign.

[18] Sabzalian, M.R., Saeidi, G. and Mirlohi, A. (2008) Oil Content and Fatty Acid Composition in Seeds of Three Safflower Species. Journal of the American Oil Chemists' Society, 85, 717-721. http://dx.doi.org/10.1007/s11746-008-1254-6

[19] Babcock, R.E., Clausen, E.C., Popp, M. and Schulte, W.B. (2008) Yield Characteristics of Biodiesel Produced from Chicken Fat-Tall Oil Blended Feedstocks. Completion Report, Project Number MBTC-2092 R. E. Department of Transportation Research and Special Programs Administration. http://www.researchgate.net/publication/253638502 Yield Characteristics of Biodiesel Produced from Chicken Fa t-Tall Oil Blended Feedstocks

[20] Rashid, U., Anwar, F. and Arif, M. (2009) Optimization of Base Catalytic Methanolysis of Sunflower (Helianthus annuus) Seed Oil for Biodiesel Production by Using Response Surface Methodology. Industrial \& Engineering Chemistry Research, 48, 1719-1726. http://dx.doi.org/10.1021/ie801136h

[21] Taravus, S., Temur, H. and Yartasi, A. (2009) Alkali-Catalyzed Biodiesel Production from Mixtures of Sunflower and Beef Tallow. Energy Fuels, 23, 4112-4115. http://dx.doi.org/10.1021/ef900211n

[22] Moser, B.R. (2008) Influence of Blending Canola, Palm, Soybean and Sunflower Oil Methyl Esters on Fuel Properties of Biodiesel. Energy Fuels, 22, 4301-4306. http://dx.doi.org/10.1021/ef800588x

[23] Vicente, G., Coteron, A., Martinez, M. and Aracil, J. (1998) Application of the Factorial Design of Experiments and Response Surface Methodology to Optimize Biodiesel Production. Industrial Crops and Products, 8, 29-35. http://dx.doi.org/10.1016/S0926-6690(97)10003-6

[24] Antolin, G., Tinaut, F.V., Briceno, Y., Castano, V., Perez, C. and Ramirez, A.I. (2002) Optimization of Biodiesel Production by Sunflower Oil Transesterification. Bioresource Technology, 83, 111-114. http://dx.doi.org/10.1016/S0960-8524(01)00200-0

[25] Duz, M.Z., Saydut, A. and Ozturk, G. (2011) Alkali Catalyzed Transesterification of Safflower Seed Oil Assisted by Microwave Irradiation. Fuel Processing Technology, 92, 308-313. http://dx.doi.org/10.1016/j.fuproc.2010.09.020

[26] Thomas, T.P., Birney, D.M. and Auld, D.L. (2013) Optimizing Esterification of Safflower, Cottonseed, Castor, and Used Cottonseed Oils. Industrial Crops and Products, 41, 102-106. http://dx.doi.org/10.1016/j.indcrop.2012.03.023

[27] Rashid, U. and Anwar, F. (2008) Production of Biodiesel through Based-Catalyzed Transesterification of Safflower Oil Using an Optimized Protocol. Energy Fuels, 22, 1306-1312. http://dx.doi.org/10.1021/ef700548s

[28] Kaya, C., Hamamci, C., Baysal, A., Akba, O., Erdogan, S. and Saydut, A. (2009) Methyl Ester of Peanut (Arachis hypogea L.) Seed Oil as a Potential Feedstock for Biodiesel Production. Renewable Energy, 34, 1257-1260. http://dx.doi.org/10.1016/j.renene.2008.10.002

[29] Nguyen, T., Do, L. and Sabatini, D.A. (2010) Biodiesel Production via Peanut Oil Extraction Using Diesel-Based Reverse-Micellar Microemulsions. Fuel, 89, 2285-2291. http://dx.doi.org/10.1016/j.fuel.2010.03.021

[30] Moser, B.R. (2012) Preparation of Fatty Acid Methyl Esters from Hazelnut, High-Oleic Peanut and Walnut Oils and Evaluation as Biodiesel. Fuel, 92, 231-238. http://dx.doi.org/10.1016/j.fuel.2011.08.005

[31] Eskin, N.A.M. and McDonald, B.E. (1991) Canola Oil. BNF Nutrition Bulletin, 16, 138-146. http://dx.doi.org/10.1111/j.1467-3010.1991.tb01048.x

[32] Jeong, G.T., Yang, H.S., Park, S.H. and Park, D.H. (2007) Optimization of Biodiesel Production from Rapeseed Oil Using Response Surface Methodology. Korean Journal of Biotechnology and Bioengineering, 22, 222-227.

[33] Xie, W., Huang, X. and Li, H. (2007) Soybean Oil Methyl Esters Preparation Using NaX Zeolites Loaded with KOH as a Heterogeneous Catalyst. Bioresource Technology, 98, 936-939. http://dx.doi.org/10.1016/j.biortech.2006.04.003

[34] Alptekin, E. and Canacki, M. (2010) Optimization of Pretreatment Reaction for Methyl Ester Production from Chicken Fat. Fuel, 89, 4035-4039. http://dx.doi.org/10.1016/j.fuel.2010.04.031

[35] Alptekin, E. and Canacki, M. (2011) Optimization of Transesterification for Methyl Ester Production from Chicken Fat. Fuel, 90, 2630-2638. http://dx.doi.org/10.1016/j.fuel.2011.03.042

[36] Kondamudi, N., Strull, J., Misra, M. and Mohapatra, S.K. (2009) A Green Process for Producing Biodiesel from Feather Meal. Journal of Agricultural and Food Chemistry, 57, 6163-6166. http://dx.doi.org/10.1021/jf900140e

[37] Guru, M., Koca, A., Can, O., Cinar, C. and Sahin, F. (2010) Biodiesel Production from Waste Chicken Fat Based Sources and Evaluation with Mg Based Additive in a Diesel Engine. Renewable Energy, 35, 637-643. http://dx.doi.org/10.1016/j.renene.2009.08.011

[38] Xue, J., Grift, T.E. and Hansen, A.C. (2011) Effect of Biodiesel on Engine Performances and Emissions. Renewable and Sustainable Energy Reviews, 15, 1098-1116. http://dx.doi.org/10.1016/j.rser.2010.11.016

[39] Moreno, F., Muñoz, M. and Morea-Roy, J. (1999) Sunflower Methyl Ester as a Fuel for Automobile Diesel Engines. 
Transactions of the ASAE, 42, 1181-1185. http://dx.doi.org/10.13031/2013.13283

[40] EPA (2004) Control of Emissions of Air Pollution from Nonroad Diesel Engines and Fuel; Final Rule. USEPA, Washington DC. http://www.regulations.gov/\#!documentDetail;D=EPA-HQ-OAR-2003-0012-1104

[41] Santos, B.S., Capareda, S.C. and Capunitan, J.A. (2013) Engine Performance and Exhaust Emissions of Peanut Oil Biodiesel. Journal of Sustainable Bioenergy Systems, 3, 272-286. http://dx.doi.org/10.4236/jsbs.2013.34037

[42] SAE (2008) SAE J 1349: Engine Power Test Code-Spark Ignition and Compression Ignition—Net Power Rating. SAE, Troy, MI. http://standards.sae.org/j1349_200803/

[43] Lin, B.F., Huang, J.H. and Huang, D.Y. (2009) Experimental Study of the Effects of Vegetable Oil Methyl Ester on DI Diesel Engine Performance Characteristics and Pollutant Emissions. Fuel, 88, 1779-1785. http://dx.doi.org/10.1016/j.fuel.2009.04.006

[44] Qi, D.H., Geng, L.M., Chen, H., Bian, Y.Z.H., Liu, J. and Ren, X.C.H. (2009) Combustion and Performance Evaluation of a Diesel Engine Fueled with Biodiesel Produced from Soybean Crude Oil. Renewable Energy, 34, $2706-2713$. http://dx.doi.org/10.1016/j.renene.2009.05.004

[45] Ozsezen, A.N., Canakci, M., Turkcan, A. and Sayin, C. (2009) Performance and Combustion Characteristics of a DI Diesel Engine Fueled with Waste Palm Oil and Canola Oil Methyl Esters. Fuel, 88, 629-636. http://dx.doi.org/10.1016/j.fuel.2008.09.023

[46] Oğuz, H., Öğüt, H. and Eryilmaz, T. (2007) Investigation of Biodiesel Production, Quality and Performance in Turkey. Energy Sources, Part A: Recovery, Utilization, and Environmental Effects, 29, 1529-1535. http://dx.doi.org/10.1080/15567030600820567

[47] Pulkrabek, W.W. (2004) Engineering Fundamentals of the Internal Combustion Engine. 2nd Edition, Pearson Prentice-Hall, Upper Saddle River.

[48] Kaplan, C., Arslan, R. and Sürmen, A. (2006) Performance Characteristics of Sunflower Methyl Esters as Biodiesel. Energy Sources, Part A: Recovery, Utilization, and Environmental Effects, 28, 751-755. http://dx.doi.org/10.1080/15567030600820567

[49] Kumar, N., Varun and Chauhan, S.R. (2013) Performance and Emission Characteristics of Biodiesel from Different Origins: A Review. Renewable and Sustainable Energy Reviews, 21, 633-658. http://dx.doi.org/10.1016/j.rser.2013.01.006

[50] Muñoz, M., Moreno, F. and Morea, J. (2004) Emissions of an Automobile Diesel Engine Fueled with Sunflower Methyl Ester. Transactions of the ASAE, 47, 5-11. http://dx.doi.org/10.13031/2013.15859

[51] Nabi, M.N., Hoque, S.M. and Akhter, M.S. (2009) Karanja (Pongamia pinnata) Biodiesel Production in Bangladesh, Characterization of Karanja Biodiesel and Its Effect on Diesel Emissions. Fuel Processing Technology, 90, 1080-1086. http://dx.doi.org/10.1016/j.fuproc.2009.04.014

[52] Moser, F., Schlogl, H. and Wiesbauer, H. (1989) Behaviour of Rape Seed Oil Methyl Ester Fueled Tractor Engines and Field Experience. Proceedings of the CEC International Symposium on the Performance Evaluation of Automotive Fuels and Lubricants, CTCM/EFTC, Paris, May 1989.

[53] Canacki, M. and Van Gerpen, J.H. (2003) Comparison of Engine Performance and Emissions for Petroleum Diesel Fuel, Yellow Grease Biodiesel, and Soybean Oil Biodiesel. Transactions of the ASAE, 46, 937-944.

[54] Puhan, S., Vedaraman, N., Ram, B.V.B., Sankarnarayanan, G. and Jeychandran, K. (2005) Mahua Oil (Madhuca indica Seed Oil) Methyl Ester as Biodiesel-Preparation and Emission Characterstics. Biomass and Bioenergy, 28, 87-93. http://dx.doi.org/10.1016/j.biombioe.2004.06.002

[55] Utlu, Z. and Kocak, M.S. (2008) The Effect of Biodiesel Fuel Obtained from Waste Frying Oil on Direct Injection Diesel Engine Performance and Exhaust Emissions. Renewable Energy, 33, 1936-1941. http://dx.doi.org/10.1016/j.renene.2007.10.006

[56] Wu, F., Wang, J., Chen, W. and Shuai, S. (2009) A Study on Emission Performance of a Diesel Engine Fueled with Five Typical Methyl Ester Biodiesels. Atmospheric Environment, 43, 1481-1485. http://dx.doi.org/10.1016/j.atmosenv.2008.12.007

[57] Puhan, S., Vedaraman, N., Sankaranarayanan, G. and Ram, B.V.B. (2005) Performance and Emission Study of Mahua Oil (Madhuca indica Oil) Ethyl Ester in a 4-Stroke Natural Aspirated Direct Injection Diesel Engine. Renewable Energy, 30, 1269-1278. http://dx.doi.org/10.1016/j.renene.2004.09.010

[58] Aydin, H. and Bayindir, H. (2010) Performance and Emission Analysis of Cottonseed Oil Methyl Ester in a Diesel Engine. Renewable Energy, 35, 588-592. http://dx.doi.org/10.1016/j.renene.2009.08.009

[59] Karabektas, M. (2009) The Effects of Turbocharger on the Performance and Exhaust Emissions of a Diesel Engine Fuelled with Biodiesel. Renewable Energy, 34, 989-993. http://dx.doi.org/10.1016/j.renene.2008.08.010

[60] Buyukkaya, E. (2010) Effects of Biodiesel on a DI Diesel Engine Performance, Emission and Combustion Characteris- 
tics. Fuel, 89, 3099-3105. http://dx.doi.org/10.1016/j.fuel.2010.05.034

[61] Ramadhas, A.S., Muraleedharan, C. and Jayaraj, S. (2005) Performance and Emission Evaluation of a Diesel Engine Fueled with Methyl Esters of Rubber Seed Oil. Renewable Energy, 30, 1789-1800. http://dx.doi.org/10.1016/j.renene.2005.01.009

[62] Ulusoy, Y., Tekin, Y., Cetinkaya, M. and Karaosmanoglu, F. (2004) The Engine Tests of Biodiesel from Used Frying oil. Energy Sources, Part A: Recovery, Utilization, and Environmental Effects, 26, 927-932. http://dx.doi.org/10.1080/00908310490473219

[63] Fontaras G., Karavalakis, G., Kousoulidou, M., Tzamkiozis, T., Ntziachristos, L., Bakeas, E., et al. (2009) Effects of Biodiesel on Passenger Car Fuel Consumption, Regulated and Non-Regulated Pollutant Emissions over Legislated and Real-World Driving Cycles. Fuel, 88, 1608-1617. http://dx.doi.org/10.1016/j.fuel.2009.02.011

[64] Canacki, M. (2005) Performance and Emissions Characteristics of Biodiesel from Soybean Oil. Proceedings of the Institution of Mechanical Engineers, Part D: Journal of Automobile Engineering, 219, 915-922. http://dx.doi.org/10.1243/095440705X28736

[65] Labeckas, G. and Slavinskas, S. (2006) The Effect of Rapeseed Oil Methyl Ester on Direct Injection Diesel Engine Performance and Exhaust Emissions. Energy Conversion and Management, 47, 1954-1967. http://dx.doi.org/10.1016/j.enconman.2005.09.003

[66] Sahoo, P.K., Das, L.M., Babu, M.K.G. and Naik, S.N. (2007) Biodiesel Development from High Acid Value Polanga Seed Oil and Performance Evaluation in a CI Engine. Fuel, 86, 448-454. http://dx.doi.org/10.1016/j.fuel.2006.07.025

[67] Carraretto, C., Macor, A., Mirandola, A., Stoppato, A. and Tonon, S. (2004) Biodiesel as Alternative Fuel: Experimental Analysis and Energetic Evaluations. Energy, 29, 2195-2211. http://dx.doi.org/10.1016/j.energy.2004.03.042 